\title{
THE HIPSTER SUBCULTURE AND ITS REPRESENTATION IN LENA DUNHAM'S TV SERIES GIRLS
}

\author{
MARÍA DOLORES NARBONA CARRIÓN \\ University of Málaga \\ narbona@uma.es
}

Received 18 February 2021

Accepted 30 November 2021

KEY WORDS: Hipster; Lena Dunham's Girls; subculture; TV series; feminism.

PALABRAS ClAVE: Hipster; Girls, de Lena Dunham; subcultura; series de televisión; feminismo.

\begin{abstract}
Hipsters are considered as one of the most relevant American subcultures at present. However, the term hipster is notoriously difficult to define and has not received sufficient academic attention, especially when referring to women. Thus, one of the main objectives of this interdisciplinary study is to reverse this situation by bringing to light information and bibliography about this prominent cultural phenomenon in the US context. To prove its importance, this theoretical aspect will be complemented by its practical implementation, as this essay includes the evaluation of the representation of the hipster in one of the main cultural products which have reflected it, television and, more concretely, in Lena Dunham's TV series, Girls. This analysis responds to the aim of discerning if Girls's alleged hipsterism can be considered authentic and of elucidating the reasons that may have led Dunham to this choice for the creation of her characters and, also, for her self-branding.
\end{abstract}

\section{RESUMEN}

Los hipsters son la subcultura norteamericana más relevante de nuestros dias. Sin embargo, el término hipster es muy dificil de definir $y$ no ha recibido suficiente atención académica, especialmente en relación a las mujeres. De ahí que uno de los principales objetivos de este este estudio multidisciplinar sea revertir esta situación sacando a la luz información y bibliografia sobre este prominente fenómeno 
cultural en el contexto estadounidense. Para demostrar su importancia, este aspecto teórico se complementará con su implementación práctica, ya que este ensayo incluye la evaluación de la subcultura hípster en uno de los productos culturales que lo ha reflejado, la televisión y, más concretamente, la serie de Lena Dunham, Girls. Este análisis responde al propósito de discernir si el supuesto hipsterismo de Girls se puede considerar auténtico y el de dilucidar las razones que han podido llevar a Dunham a elegirlo para la creación de sus personajes e incluso para la de su propia marca personal.

\section{INTRODUCTION AND METHODOLOGY}

Lena Dunham's TV series Girls (HBO, 2012-2017) appeared as both a successor and a counterpoint to its amazingly successful predecessor, Sex in the City (1998-2004) (McRobbie 2015, 13; Grant and Nash 61; Lehman 10; McCann 93; Stuever). Popular media communicators and specialized scholars coincide in the recognition that, no matter the parallelisms between these two shows, contrary to the four overtly snob protagonists and environment of Sex in the City, those of Girls possess most of the characteristics that are traditionally considered essential to the generation which suffered the consequences of the Great Recession ${ }^{1}$ that it was representing, which is commonly known as "millennial" and which shares many features with hipsters (Genz 2017, 18). Added to this, a number of critics have fostered the relation between Girls and this subculture, describing the series as "the hipster-fied Sex in the City" (Winchell), "the Sex in the City of the hipster generation" (Ruíz) or "a hipster iteration of Sex and the City" (Miller). Hank Stuever considers that Girls has even been endowed with the responsibility of portrayingalmost as if it was a documentary rather than a dramedy-"all overeducated, underemployed, mostly white urban hipsters in their 20s." In fact, this is the impression that Girls's creators have been giving even before its premiere, with a casting call literally "Seeking Hipster Types" ("HBO's Girls"). Notice that, even if this casting call looked literally for "hipster types of all ethnicities," Girls has almost exclusively portrayed white characters. This is a very interesting subject because-as will be shown later-hipsterism is heavily rooted in Black culture, and it deserves further study in the future.

${ }^{1}$ Maryann Erigha situates this recession from 2008 to 2011 (140). 
As Michael Scott clearly asserts-in line with other salient researchers such as Wes Hill, Janna Michael, Mark Greif, René Bogović or Bjørn Schiermer-“'hipster' and 'hipsterism' are notoriously difficult to define" (63). Although the existence and relevance of hipsters in our society is inarguable, experts coincide in recognising that there are very few solid studies on them and that there is "a neglect of the hipster phenomenon on the part of academic sociology," 2 as professor Schiermer explains. She has declared that her article "Late-modern Hipsters: New Tendencies in Popular Culture" (2014) "presents a first attempt to overcome this lacuna" (168). To Schiermer this disregard contrasts glaringly with the amazing amount of attention that hipsters arouse outside academia, as the millions of opinions given by journalists, bloggers and layman experts of all categories have demonstrated (168). Consequently, this study is going to consider not only the academic works on the subject that exist, but also other different types of sources because, as professor Shane Blackman defends, the complex origin and development of subcultural theory has been shaped by both academic and popular usage (496). Besides, following contemporary audience research by experts such as Stuart Hall, David Morley or Henry Jenkins, I will also consider the active role of TV viewers, who are perfectly able to critically analyse and engage with media products (Saisi 64), especially in our examination of the reaction of Girls's audience to its portrayal of hipsters contained in their own reviews or those of critics.

Besides, experts coincide in highlighting the fact that most definitions of hipsters are centred on male cases, but little attention is given to female hipsters (Greif xiii; Baumgardner 95; Tortorici 122). This scarcity of academic research on the study of women in subcultures and countercultures in general has been documented and analysed in depth by salient scholars such as Angela McRobbie (1991) and Wivian Weller (2006), among others. The latter, who analyses this subject in "The Feminine Presence in Youth Subcultures: The Art of Becoming Visible," concludes that there have been few references or none at all regarding female participation in these groups. Lena Dunham has contributed to the subversion of this situation in the particular field of mass media, in which the

2 The present study may also contribute to the amelioration of this situation by offering an extensive bibliographical section that can be useful for future academic studies on this subject. 
almost absence of active or insubordinate feminine roles has also been recognised by experts such as Laura Mulvey and Tania Modleski. Subsequently-even if we are going to refer to male hipsters, too-, Lena Dunham and her unconventional female characters become especially interesting in this innovative research field.

Notwithstanding the above-mentioned complications in relation to the definition of the term "hipster" and in connection with the methodology that informs this investigation, it is my aim to depict the main features of hipsterism also with the objective of analysing to what extent they can actually be recognised in Girls. In my study, I will follow Douglas Keller's "multiperspectival" proposal (43), which can be connected to Horace Newcomb's interdisciplinary and plural methodological recommendations, which he considers necessary for the study of television, given its multifaceted nature (24-25). However, this essay will also be particularly influenced, for example, by social theorists, who, as Kellner explains, highlight that the role of mass media and communications in the reproduction of contemporary societies is so important, that we should consider them as their major institutions, given also their wide range of effects: economic, political, cultural and social (30). Consequently, I will consider socio-cultural works which include the study of subcultures with the intention of discerning the elements that are associated to hipsterism. Once they have been identified, a qualitative analysis of the content of Girls will follow. It will portray a comparative study of the main features of its characters with those proper of hipsters, with special focus on its female personae, and we will try to discern to what extent it is accurate to apply them the hipster label that they have been popularly assigned.

These observations are going to be used as a route to a broader cultural diagnosis. It includes reflections on how those characteristics have been used by its creator, and on the reasons which might have motivated Dunham's apparent distancing from generally accepted social conventions. Thus, the present research will also contribute to answering Meredith Nash and Imelda Wheleham's query about Dunham's challenging representations of millennials when they wonder if they simply incarnate "unlikable hipster slackers" or if there is "a cogent socio-political argument underpinning this 'dramedy" (1).

In this vein and parting from the importance of appearances in hipsterism, structuralist studies related to the sociology of fashion, 
such as those of Georg Simmel, will be very illuminating. Considering Dunham's recurrent insistence on her irrevocable feminist positioning, underlined with assertions such as "I just think feminism is my work [...] It is everything to me because it sort of is everything" (Dunham quoted in Gay), this article will also contemplate the possibility that her characters' deviations may respond to the feminist intention of subverting certain feminine oppressive stereotypes. For this purpose, it is going to be also necessary to base our inferences on relevant feminist works, among which those of Angela McRobbie, Wallis Seaton, Stéphanie Genz, Hannah McCann and Akane Kanai, dealing with post-feminism in our neoliberal social context, stand out. In this line, I have also applied a biographical critical perspective-traditionally used in literary criticism-to the analysis of Girls, a practice that is justified by the strong association that Dunham herself makes between her real life and that of her fictional character, Hannah Horvath.

Related to this is the influence of reception theory on this work, as it does not only pay attention exclusively to textual elements proper of the series, because, as McRobbie explains, it is "accompanied and even supplanted by many other forms of social media" $(2015,14)$. In effect, as McRobbie notes, the series itself becomes just one element of the whole narrative landscape created by Dunham (14), ${ }^{3}$ which includes supposedly authentic elements from her own life. This practice leads to the consideration of the process of construction of identity (or self-branding) as a product to be consumed by others (Genz 2015, 546). It also blurs the boundaries between producers and products, which is a very common practice in neoliberal marketing strategies that appeal to affects, (commodified) authenticity and personal narrativization (Genz 2015, D. Murray 2013). Another aspect related to this reception theory critical perspective is our consideration of viewers' opinions-as mentioned before-, and broader socio-historical and political issues.

The content of the ensuing sections follows the order previously described, beginning by the illustration of the state of the art, with the objective of contributing to the clarification of the term "hipster," a core concept for this study.

\footnotetext{
${ }^{3}$ Seaton analyses other intertextual elements of self-promotion and self-representation used by Dunham that lead to access and consumption of her work, such as her prolific activity on platforms such as Instagram (156).
} 


\section{ORIGINS AND STUDY OF HIPSTERS}

Mark Greif has studied in depth this cultural phenomenon in What Was the Hipster? (2010), whose title seems to imply that hipsters only existed in the past. In effect, Greif dates their "death" in 2003 (60), but Sophie Bot affirms that she started to notice their increasing relevance in 2006 (20), Kinzey considers that this subculture is among the most important ones of our time (2), and Robert Lanham affirms that "hipsters are everywhere" (1). Nevertheless, Schiermer concludes that Greif might be right in the sense that the original hipsters have disappeared, but he has ignored the fact that "the hipster ethos is more alive than ever" (178), as we will also demonstrate with the analysis of its presence in Girls. However, the importance of Greif's book is unquestionable and here he also laments that "the study of the hipster, as opposed to the punk, hippie, raver, goth, cyber-utopian or b-boy, has not yet drawn its scholars" (xix).

The state of the art has not varied considerably with the passing of time, even if more recent studies by experts such as Ico Maly and Piia Varis demonstrate that the term "hipster" not only has become very popular all over the world, but it has also attracted academic attention (637). Nevertheless, Maly and Varis only mention five authors to support this assertion and limit their references basically to essays. More recently-in 2020-professor Margaret Anne Murray complained that most academic research on hipsters is limited to either focusing on them as a mere consumer segment (e.g. Arsel and Thompson, and Rademacher and Casey) and are, consequently, basically centred on the analysis of their style; or to the examination of how they are discussed online (e.g. Maly and Varis), or to their analysis by journalists and the popular press (e.g. Schiermer) (457).

With regards to the etymology of the term "hipster"-which may also throw some light in the present study-there is a great deal of controversy because the word "hip" is an example of lexical polygenesis (Jackson). ${ }^{4}$ However, in order to understand the contemporary hipster, we should bear in mind-though very concisely-its origins. These are rooted in Afro-American culture, as they were connected to the particular language that slaves used in

\footnotetext{
4 Jackson explains the complexity of the actual meaning of the word "hip" by adding that it not only has multiple proposed etymologies but it also may have multiple, confluent origins, which we are briefly exposing in this section.
} 
the seventeenth century (Leland), to the distinct lifestyle of Harlem artists (Arsel and Thompson 795), and to the subsequent black subcultural figure of the late 1940s (Broyard). Norman Mailer, in his influential essay of 1957, highlighted that hipsters shared with "the Negro" their rebelliousness (278), their "courage to be individual" (277). From these notions derives one the most significant characteristics of hipsters that have remained in the collective notion of what they are: nonconformity with respect to what is socially or mass accepted. As Charles Petersen points out, even if modern hipsters have taken this term from the 1940s-50s, the vast majority of people who used it later forgot its history and connection to these previous connotations (qtd. in Greif 61), which have mostly turned into mere simulation (Lorentzen) and even "a marketable good" (Bogović 5). ${ }^{5}$

The complications involved in the definition of the hipster are, also, connected to how complex it is to circumscribe the wider term "subculture" in which the former is inserted, because it possesses a dynamic (Jenks 2-3, 6) and ambiguous nature (Wolfgang and Ferracuti 95). According to Mike Brake, "subcultures exist where there is some form of organized and recognized constellation of values, behaviour and action which are responded to as different from the prevailing set of norms" (8-9). But, in most contemporary hipsters, it is problematic to recognize this profundity because the set of values that are supposed to lead their behaviours is not so evident, as we are going to debate later, in the particular case of Lena Dunham.

In this context, it is not surprising to realise how experts such as Jackson and Greif have concluded that the definition of "hipster" is an almost impossible task. Even if Lanham's The Hipster Handbook might have provided some consensus on its modern meaning (Jackson), as Bot argues, there is not "any single definition ever agreed upon" (23). Kinzey agrees with her when he asserts that the term "hipster" has been defined in many different ways, but most of its descriptions have been false, misleading or just part of a much more complex reality (1). According to Bot, what is evident is that the popular imaginary of the hipster concentrates on negative traits which she associates with its venomous representation on the popular media (22). In effect, this term is also used derogatively in

${ }^{5}$ This is also connected to the appropriation of hipsterism by whiteness, a subject that deserves further discussion in future work in this field. 
other contexts (Greif 8, Clayton 24, Maly and Varis 628), which might explain the fact that few seem to be willing to self-identify with the hipster marker. ${ }^{6}$

Furthermore, it is not easy to distinguish the authentic ${ }^{7}$ hipster identity from the fake one nowadays. Thus, Maly and Varis's description of these two groups is very useful: "A 'real' hipster is someone who rejects being part of a social group and thus also rejects the hipster label which is reserved for people who desperately want to be 'hip' and are thus not 'real' or authentic. Nor are they true innovators or trendsetters, which the individualistic, authentic hipsters are" (646). This distinction is even more complicated nowadays because our present neoliberal economic context, after realizing the importance of this global tendency, has commodified the hipster style-this being the case of prominent brands like American Apparel or Urban Outfitters. ${ }^{8}$ Priya Elan connects this idea to the evolution of the hipster in these terms: "[The hipster] began as a runon from (anti-consumerist) slacker culture [...], [and it] has morphed into a multimillion-dollar industry trying to sell a mythical, neobohemian lifestyle." This, again, makes things hard for hipsters, who, as Deborah Cowen states, "by unspoken but practiced degree [...] must all be individual, different or else membership may be revoked" (22). In this context, it is easier to understand the assertion-à la Dolly Parton-of the supposedly hipster protagonist of Girls admitting that "it costs a lot of money to look this cheap" (Peitzman). From this declaration it can be inferred that Hannah, who is busy trying to become who she is (as she declares in the pilot episode), has chosen this "identity" that is related to hipsterism; this type of decision-taking being one of the most worrying concerns of modern citizens (Bauman 126). In this article, we will go further in our attempt to elucidate the possible reasons that may have motivated Hannah's-and/or Dunham's-selection of this particular (life)style, a choice which, following Genz, forms part of the process of self-

\footnotetext{
${ }^{6}$ Consider the number of blogs and books that poke fun at them, such as Look at This Fucking Hipster (by Joe Mande), Stuff Hipsters Hate (by Brena Ehrlich) or Hipster Hitler (by James Carr and Archara Kumar).

7 See Sarah Thornton for more information about the importance of authenticity for subcultures.

8 Many scholars have analysed the profitable marketing strategy of adopting elements from the hipster subculture, e.g.: Maly and Varis, and Bogović.
} 
branding 9 in the neoliberal "business context and market rationale that valorise both the subject and the merchandising of it, highlighting the blurring of the individual and commodity aspects of selfhood" $(2017,25) .{ }^{10}$

Related to this commodification of the hipster aesthetics emerges another complication in the attempt to define hipsters politically. This derives from the fact that-as previously hinted-they are traditionally supposed to be countercultural and leftist rebels who go against the establishment and inherited restrictions (Alfrey 28) and represent an alternative to neoliberalism and mass-produced consumption. But, the fact that relevant brands are integrating and utilising the hipster style to sell their products distorts what might have been a more evident political hipster tendency in the past. However, Maly and Varis conclude that the authenticity of a "real" hipster is not degraded by this marketing practice as far as he can offer an authentic justification for it (650). Hebdige seems to highlight a similar idea when he declares that "It is basically how commodities are used in subculture which marks the subculture off from more orthodox cultural formations" (103; my emphasis). This goes in line with the aim of this study, which is, not only to detect hipster characteristics in Girls-as other academic works criticised as superficial do (M. A. Murray 457) - but also to reflect on the possible socio-political intentions that may have motivated their use.

In connection with the close relation between hipsters and style is their preference for jobs related to the world of art and creativity, which is another popular characteristic of this subculture. In this respect, research about millennials shows that there are many coincidences in the professional characteristics of both groups, maybe because they both include people of similar ages. ${ }^{11}$ Hipsters, like millennials, tend to choose "making a life" over "making a living" (Ng. 282). However, this post-recession generation suffers the consequences of this crisis and experiences very high unemployment rates, which leads them to require the financial help of relatives and friends. Hipsters' preference for artistic jobs substantiates their

\footnotetext{
${ }^{9}$ McRobbie connects this neoliberal idea of "self-branding" to the Foucauldian concept of "human capital" $(2015,10)$.

10 This is evidently portrayed in the series when Hannah's publishers of her memoir propose her these questions: "What's your brand?", "Who are we selling?" (season 3, episode 5).

11 Erigha considers that the members of the millennial generation were "born anywhere from 1979 to $2004 "(140)$.
} 
predilection for particularly creative cities such as Los Angeles or New York City (Menger; Florida), which, consequently, reflect what has been called "hipster urbanism" (Cowen 22). Subsequently, what were originally alternative areas have also become commodified-as has happened to the hipster clothing style- or, to be more precise, gentrified. This has led to the transformation of these places into fashionable neighbourhoods to live or visit, thus causing the loss of the essential originality or authenticity of the hipster's choice.

As previously hinted, we encounter another obstacle in the attempt to apply the already problematic concept of hipsterism to women. In effect, googling "hipster," 99\% of the results refer to men. And, if we do the same with the term "female hipster," almost all the references are to fashion and superficial lists about how to fit in "the look." In the academic field, specialists recognise this same limitation and confirm that too little attention is given to female hipsters (Greif xiii; Baumgardner 95; Tortorici 122). Writer and journalist Dayna Tortorici expounds that the attempts to define this concept are unsatisfactory and mostly connected to artists-e.g.: Elizabeth Peyton, Chloe Sevigny, Kim Gordon-and "crowd-pleasers"-Zooey Deschanel, Diablo Cody and MIA-who appeal to hipster taste rather than to what she considers as authentic hipster features (122-24). This leads Tortorici to infer that "the female hipster's privileged knowledge is not subcultural, intellectual or even pseudointellectual, but the familiar 'female' knowledge of how to look" (123). Besides, focusing on this external appearance, Tortorici points out certain outstanding and mostly negative elements of the typical pose of female hipsters (130-31), which remind us of the impression of disaffection and chillness given by Girls's female characters.

This section has offered a base and a brief summary of some of the most outstanding features related to hipsters, in order to facilitate our following reflections on, and analysis of, the representation of this subculture in the TV series Girls, to which the ensuing segment is dedicated.

\section{ANALYSIS OF HIPSTERISM IN LENA DUNHAM'S GIRLS}

Due to the fact that hipsters have become so popular, television-a sagacious detector of trends-has introduced them in its programmes (Lorentzen 68). In effect, in the particular field of sitcoms, hipsters appear in a number of shows, among which are: New Girl (Fox, 2011-18), Portlandia (IFC, 2011-18), Bored to Death 
(HBO, 2009-11), Nathan Barley (Channel 4, 2005), Flight of the Conchords (HBO, 2007-9), How to Make It in America (HBO, 201011), 2 Broke Girls (CBS, 2011-17), Flaked (Netflix, 2016-17), Hipsterhood (YouTube and Blip, 2012-13), Bondi Hipsters (YouTube, 2011-) and Sunnyside (City, 2015). In this essay, attention is particularly paid to Girls (HBO, 2012-17), a comedy starring Lena Dunham, who has also created, written and frequently directed the show.

If we trust most of its reviews and advertising, we might feel tempted to label Girls as a hipster programme even before watching it. Besides, its creator incarnates many of the characteristics commonly attributed to hipsters and, not only scholars (e.g.: McRobbie 2015, 9, 13; Nash and Wheleham 3; Seaton 150), but also she herself, have repeatedly recognised that she reflects her own life and experiences in her works and characters (Poniewozik; Danes). Concretely referring to the protagonist of Girls, she has declared: "She's mine and she's me" (Nussabaum). Dunham has been connected to the world of art and culture-something proper of hipsters-from her very childhood, her father being Carroll Dunham, a painter; and her mother, Laurie Simmons, an artist and photographer. This situates her, also, in the allegedly privileged background that is commonly associated to hipsters, and involves her with their sense of narcissism and entitlement-a characteristic that is also normally associated to millennials (Park 310-11; Quenqua; Stein; Malone). Besides, Dunham has studied-like the main characters of Girls-at Oberlin College (Ohio), a small elite and alternative college (Kaklamanidou and Tally 3) with a student body that is, according to Lanham (95), $94.6 \%$ hipster. Her creations have been criticised for their lack of ethnic diversity (Erigha 152) and, more particularly, she has been accused of "hipster racism." 12 Nevertheless, specialists such as Lehman have interpreted this lack of racial diversity in Girls as a veiled criticism of the short-sighted vision common in the type of girls-either privileged hipsters or millennials - the series ironically portrays.

It is pertinent to analyse if, added to these connections of Dunham with hipsterism, some of its characteristics can actually be recognised in her TV series Girls. To begin with, a number of critics

\footnotetext{
12 For a definition of "hipster racism," see Mahdawi, West, or Lim. Other accusations of Dunham's hipster racism appear in the writings of Nash and Wheleham, Jenna Worthan, Makarechi, Dodai Stewart and Kendra James, to cite but a few.
} 
have considered that its target audience are mainly hipsters (Suebsaeng) and, as hinted before, many others have directly considered Girls as a hipster TV series (Hoare). In effect, the show seems to possess many features that go in line with the notion of the contemporary hipster that has been sketched out in the previous section, as we will detail.

In the first place, spectators can immediately associate the setting of Girls with hipsterdom, as the series is shot, not only in one the "creative cities" formerly mentioned, New York, but particularly in one of the most identifiable hipster urban areas in the world: Brooklyn. This neighbourhood was not a hipster area in the past and, as McRobbie declares, if hipsters can live there now, it is only thanks to the support of well-off parents $(2015,15)$, as happens to the protagonists of Girls (Erigha 149; Lehman 13). We would not be far from the truth if we affirmed that the places where Girls has been shot have become gentrified (Mallonee), which strengthens the series's links with hipsterism. In this sense, it should be noticed how the series portrays this ironically-thus following again this hipster feature-in the eighth episode of season 6. Here, Shoshana-one of Hannah's best friends - tries to help her friend Ray with a campaign against the hipster coffee shop that appears in front of his. She wants to distinguish Ray's place from the new one by insisting on the former's appropriateness for grown-ups. This also reinforces the idea that the expiry date of the hipster marker is the 30s, in which most experts coincide (Greif 159, Lanham 152, Schiermer 170). In effect, when Girls's characters turn around thirty, the series finishes, which also responds to HBO's industrial strategy to appeal to the millennial generation (Seaton 152). This might also occur because the protagonist eventually has a baby and this condition automatically depreciates the hipster status (Lanham 157).

Still, as the six seasons of Girls are mainly focused on the preceding years, most critics have maintained the consideration of Girls as hipster basing their inferences on the analysis of its characters, who are described as "overeducated, underemployed, mostly white urban hipsters in their 20s" (Stuever). They share typical hipster characteristics in relation to their education and occupations. Most of them are graduate students who rely on familial economic help to different degrees and share the same educational background: "the elite liberal arts" (Lehman 13) Oberlin College, which is known to encourage counter-cultural and artistic students (Erigha 144). Maybe as a consequence, most of these youngsters are 
connected to creative activities that are commonly associated to hipsters: Hanna-who is said from the beginning not to be "meant for a job in the traditional sense" (season 1, episode 5)-begins as an unpaid intern who tries to make a living out of her writing (added by her temporary position as a coffee barista at Café Grumpy); Jessa fluctuates among diverse jobs while being attracted to painting; and Marnie moves in the art circles of curating and singing. Their male counterparts are in the worlds of bartending (Ray), multimedia, music and architecture (Charlie), carpentry and acting (Adam), and show business (Elijah). The realism of the precariousness and instability of their respective jobs-proper of the post-recession eraresponds also to the search for authenticity that characterises the hipster subculture and which the creator of the series and many of its critics continuously defend (Johnson 186; Genz 26). ${ }^{13}$ However, their relatives' financial support favours their approximation to the hipsters' ideals, making it possible for them to "imagine themselves as artists, outside of the mainstream" (Erigha 150).

Concerning the social relations of Girls's main characters and, in particular, its female characters, Genz, who sees in them the prototypical incarnation of "recessionary neoliberal girls," highlights also how, instead of forging the affective bonds promoted by postfeminism, they are "trying to undo one another in their search for the most meaningful (i.e. valuable) identity" (22). In this vein, the case of Hannah is the most outstanding, because, as Genz explains, her professional obssession with narrativising her self (to make profit of it) has provoked an intense disconnection and "egotistic lack of interest in others" $(2017,24)$. Added to this, all Girls characters illustrate the typical hipster distancing from familial conventions and follow very relaxed sexual conducts, being open to new experiences and free love.

In connection to what has been exposed about hipsters' fashion and habits, most critics coincide in considering them just the opposite to the fashionistas of Sex in the City and in highighting their lack of involvement in consumer culture (e.g.: Hamilton 47, and Genz 2017 , 18). For example, according to Johnson, the selection of music in the series-which she analyses in her article-goes beyond commercial themes, thus revealing, again, the hipster's search for

\footnotetext{
${ }^{13}$ In effect, most of the characteristics of the working life of Girls's characters respond to those reflected by academic studies of American people their same age. See, for example De Hawu and De Vos's article.
} 
originality. Besides, all these twenty-somethings are frequently portrayed wearing unconventional clothing and tattoos, slacking, riding bicycles, listening to indie music and participating in cultural and artistic activities and events. Their conversations not only reflect the tipically hipster unconventionality but also border the frontiers of political correctness, especially when dealing with delicate themes like euthanasia, abortion or homosexuality, which has caused ardent critical reactions (Suebsaeng).

The analysis of hipsterism in the programme's female characters in particular is especially interesting, as hinted before. In effect, Tous Ruvirosa, following Elena Galán, considers fiction series as the ideal vehicle for the portrayal of the current diversity of women and gender relations, thus facilitating a distancing from previous dominant traditional stereotypes (72). This is evident in Dunham's representation of a "femininity that breaks down at least some of the norms we have come to expect in mainstream viewing" (McCann 94). In effect, even if Dunham has kept on focusing mainly on white female characters, her depiction of "flawed women" (McCann 95) diverges from traditional female film and TV representations, as her shows portray types of women who, like hipsters, reject conventions. Alan Sepinwall supported this vision when he also recognised that Dunham's series stood out because it showed on the screen imperfect ${ }^{14}$ female characters, which were then very infrequent. We have to admit that this situation has changed-maybe ignited by Girls' innovations-and contemporary TV screens show more original female characters in series such as Enlightened (HBO, 2011-13), Homeland (Fox 21, 2011-15), Veep (HBO, 2012-15), Scandal (ABC, 2012-18), Bunheads (ABC, Family 2012-13) and The Mindy Project (Fox and Hulu, 2012-17) (Worthan).

Nevertheless, as we affirmed previously, we still encounter the complexity underlying a proper definition of the concept "female hipster" when trying to discern if the protagonists of Girls can be particularly categorised as "hipsters." However, in the preceding section, we have highlighted some of its characteristics, many of which are present in Dunham's girls. For example, we can affirm that the female-hipster's impression of dissatisfaction and disillusionment described by Tortorici (130-31) can be noticed in its protagonists, who rarely show any enthusiasm towards what

\footnotetext{
${ }^{14}$ In her choice of the imperfect, Dunham portrays the rejection of the neoliberal (self-) impositions on "the perfect woman," that McRobbie criticises (2015).
} 
surrounds them. Instead, these girls seem to wander in their "chaotic unscripted lives" (Bell 364) without a clear track, in an "endless state of becoming" (Genz 2017, 21). Their external aspect matches their behaviour, which is also unconventional and distances itself from the mainstream, ${ }^{15}$ especially in the case of Hannah. According to Jennifer Rogien-her costume designer-this is justified by the fact that Hannah "doesn't really know that much about clothing" (qtd. in Rosenberg). These commentaries revolve around the idea that the style of Girls' characters looks for realism (Johnson 187, Schwart). Even Hannah's non-slender body "can be read as a symptom of her self-assumed authenticity and criticality" (Genz 2017, 26). ${ }^{16}$ Thus, Hannah's physique also represents her rejection of the aesthetic feminine impositions derived from neoliberal society's requirements which promote "a pleasing and approachable femininity" (Kanai 60) and try to maintain existing power relations (McRobbie 2015, 3, 10). ${ }^{17}$ Besides, the protagonist's outfits are sometimes so original and odd because they have been arranged in order to make them fit wrong and tug, as Dunham and her costume designer have admitted (Mau; Schwart). Consequently, it seems that Dunham wants to distance Hannah from dominant trends-as hipsters do-and from fashion, which seems to emphasise her freedom and rebellion against the subjugation that it normally conveys, as Simmel explains (541). But Dunham goes further still in wanting her character to look even more original than the stereotypical female hipsters that Tortorici-for example-described. Accordingly, it might also be inferred that, at least in her intention of being different from conventional appearances, Hannah is portrayed as an "authentic hipster," a "true innovator," in Maly and Varis's terminology. Hannah's oddness might also respond to her artistic nature-proper of hipsters-because, according to Mark Banks, many artists promote an eclectic and eccentric appearance that the rest of society

\footnotetext{
15 The controversial term "mainstream," analysed and criticised in detail by scholars like Thornton, Hebdige or Huber, is used in this study referring basically to what subcultures try to subvert, to mass culture, to what is socially accepted by the majority.

16 In this sense, it must be recognised that Hannah is not characterised precisely by hipsters' supposed love for homemade, vegan, organic and healthy eating (Spiegel) as she is rather portrayed compulsively eating unhealthy food quite frequently.

17 However, Hannah's body contrasts with the conventionally attractive bodies of the rest of the female cast, as Genz also highlights (26), which complicates the interpretation of Girls as a genuine attempt to break with traditional female representations.
} 
might interpret as a consequence of their experimental life and creative activities, which Simmel also associates to the "teleological individual" (543) who does not passively imitate dominant fashions. Consequently, they cannot be considered as mere "creatures of the group" or "a vessel of the social contents" (Simmel 543).

Therefore, due to Hannah's unconventional aspect and behaviour, ${ }^{18}$ among the female characters that inhabit Girls, she is one of the most appropriate candidates for being considered a hipster. She is a post-collegian moving to a big city looking for a job, possessing enormous reserves of what Pierre Bourdieu termed "cultural capital" waiting to be activated. She shares other traits of Greif's hipsters: she is income-poor temporarily but she is likely to possess the security derived from previous, parental class status and she expects to succeed at classing up. By the end of the show, Hannah, also like the older hipsters described by Greif, approaches her thirties and gives the impression of being about to fall out of subculture and fall upward into the mainstream (163). Thus, at that moment, we see how the protagonist of Girls starts to settle down: she has a baby and moves upstate to a very comfortable house, close to the place where she has found a stable job as a professor to teach something as vague and implausible as "the internet" (Vanarendonk). She leaves the city and seems to relinquish her idea of being a writer: she renounces the dream of living an unstable but more creative (hipster-like) life.

The association of Dunham's protagonist with hipsters resides also in her sharing their lack of serious and solid commitment to any social cause. Although they have traditionally represented rebelliousness against conventions, which is normally associated to leftist tendencies, contemporary hipsters are not exactly defined by their boasting of being leaders of any type of societal change, as illustrated in the previous section. Instead, after having lost their genuine radicalism, they simply "create a fashionably rebellious image" (Kelsey). This is evident, for example, in the final season of Girls, where Hannah reflects her lack of real active involvement when

\footnotetext{
18 These are some examples from the many that might be mentioned here: she plays ping-pong naked (in season 2, episode 1); in the very funeral of her husband-who was Hannah's publisher-, she asks a grieving widow to find her a new one (in season 3 , episode 5); she pulls Jessa - one of her friends-out of rehab (in season 3, episode 2); she goes to her parents' hotel room under the effects of drugs (in the "Pilot"); and in a fit of anxiety, she sticks a Q-tip in her ear and harms herself (in season 2, episode 9).
} 
she describes to a magazine editor what she considers one of her strengths: "I have a strong opinion about everything, even topics I'm not informed on."

This section has analysed the content of Girls that is popularly supposed to reflect many of the characteristics of hipsterism that had been presented in the previous section, in an attempt to apply the theory that exists about this subculture to the study of this particular case. This leads to the final section, containing the inferences that we can make from this research and the reflection on the possible reasons that may have led Dunham to choose this particular life-style or subculture for her most famous creation to this day.

\section{CONCLUSIONS}

The limited number of academic studies concerning the hipster phenomenon and their limitations has been portrayed. However, parting from them and with the help of other resources, it has been possible to trace some of its main characteristics, even with respect to its almost ignored female members. This has facilitated the attainment of another objective of this study, which was to check if some of the main features of hipsterism were actually present in the TV series Girls. Our affirmative conclusions-even if with some specifications to be taken into account-have validated its creators' considerations about the show, as well as those of many television critics, journalist, reviewers and members of the audience. In this process, we have encountered and exposed other obstacles for the detection of hipster features in this programme. Among them are the similarities between some of the characteristics proper of contemporary hipsters and those of millennials, due to the fact that the former constitute less a counter-culture than what might be called a mere life-style or even a way of representing identity in the post-recession era, a period that both groups share. This study, with its attempts at offering a proper description of the hipster and the analysis of its portrayal in Girls, has also managed to palliate this confusion.

Added to this, it has been demonstrated that Dunham shares with hipsters their thirst for authenticity, which leads to an evident distancing of Girls from previous idealised TV series about women. In effect, as Genz explains, in the case of Girls, authenticity is promoted as an affective commodity which is crucial in the self-branding 
process that the neoliberal logic insistently encourages $(2017,18)$. However, this search for realism has not been completely successful, as many voices from the audience complain (McCann 95-96; Vanarendonk), and some of its exaggerations-such as those affecting their physical appearance or actions-have led Nash and Wheleham to label its characters as "unlikeable hipster slackers" (1). This representation has led to very negative reactions on the part of hipster viewers (Weese), which can be detected in critical reviews that accuse Girls of having portrayed the worst kind of hipsters that exist (Norton) and which complain that the show gives the impression that hipsters are the least likable people in the world (Elan). In effect, from this study, it can be inferred that Dunham is not certainly favouring a positive image of hipsterism, thus confirming Bot's theory that popular media have fostered the negative vision of this subculture (22).

Considering our previous exposition, we can reflect on the reasons that might explain this unfavourable portrayal, which constitutes one of the objectives of this essay. The first one can find its roots precisely in one of the main characteristics of hipsterism, which is irony. ${ }^{19}$ Lena Dunham's weird representation of her characters can respond to her ironic vision of this subculture, which might motivate her "poking fun at its characters' race and class priviledge" (Lehman 13) and turns her into their "sharpest and ultimate critic" (Bell 363). In view of professor Wampole's thoughts, this justification merely based on irony gives the impression of rather constituting an excuse, because, in her own words, "the ironic frame functions as a shield against criticism" which "allows a person to dodge responsibility for his or her choices, aesthetic and otherwise." What is evident is that, no matter whether Dunham portrays hipsterism in her TV series authentically or ironically-as reflected before-, in the end, she has obtained a lot of benefits from her initiative, which has allowed her to progress-speaking in Bourdieu's terms-in her cultural, social and economic capitals ("Lena Dunham Cashes in"; C. Danes; Weissman). Maintaining the coincidences between herself and her famous Hannah, Dunham, in her thirties, moved from the hipster

\footnotetext{
${ }^{19}$ Most experts consider that irony is one of the main characteristics of hipsters. For example, professor Christy Wampole describes the hipster as "merely a symptom and the most extreme manifestation of ironic living." Connected to this ironic explanation of the weird portrayal of hipsters in Girls is its interpretation as attempts to create humour (Bell 366, Nash and Wheleham 5). But this would also convey socio-political implications that would deserve further attention.
} 
neigbourhood of Williamsburg to the posh West Village "to liberate her from the pressures of her uber-trendy peers" and she literally thanks God because she is now back amongst her tribe (Pluralist). Inevitably, these assertions do not facilitate our consideration of her hipsterism as very genuine or authentic, but rather connected to the fake one previously described by Maly and Varis.

Another possible motivation for the above-mentioned bizarre and exaggerated features of Girls's hipster characters might be the hipster's requirement to be creators, originators, and not mere followers of others' trends. The analysis of Girls leads us to recognise that it actually follows what Greif marks about hipsterism when he describes it as "the mechanism of the assertion of distinction" (47). This originality has provided Dunham the opprotunity to introduce a very profitable product in the market of mass media: the female hipster, a type of character who-as previously portrayed-by the time of its premiere was almost absent from TV shows. However, in the same way as many of the traits of hipsters have been commodified and have become mainstream, other TV programmes have adopted some of the unconventional characteristics of this type of original women, as we have also demonstrated before. Consequently, as Bot elucidates referring to the hipsters' yearning for originality, "people are no longer shocked as easily" (54) and "early adopters have had to go further and further into obscure fashions in search of something new" (48). In this context, Dunham gives the impression of being one of these "early adopters" who struggles to distinguish-and selfbrand-herself and her creations by using shocking elements that attract the spectators' attention. Because, as Simmel explains, "Whatever is exceptional, bizarre, or conspicuous [...] exercises a peculiar charm" (546).

In effect, Simmel has been illuminating for my attempt to understand Dunham's motivations which, after this analysis, I find connected to her personal thirst for notoriety rather than to genuine socio-political purposes. Simmel makes it clear that those who live up to the social forms prescribed by their class gain no conspicuousness or notoriety, whereas infractions and oppositions are immediately noticed and place "the individual in an exceptional position by calling the attention of the public to his action" (548). In this same line, Akanae Kanai, following Alice E. Marwick, explains how in what the latter calls "attention economy," the value of items depends on the attention they can attract in an environment of media saturation (64). Consequently, we can infer, at least, that 
Hannah and Dunham herself are increasing their values by adopting the hipster aesthetics that distances them from conventionalities, which is also in line with the brand requirements of HBO, mainly based on pushing boundaries (Genz 27) and promoting controversy (Nash and Whelehan 3). ${ }^{20}$

Finally, Dunham's choice of the hipster non-conventional aesthetics and lifestyle for her and her characters-especially Hannah-might also be related to their alledged feminist interests. We might infer that Dunham, with Hannah's rejection of what is fashionable and socially accepted, is subverting the historically weak social positon of women that doomed them to adher to the generally accepted and what is proper (Simmel 550). However, bearing in mind Dunham's evident interest in self-branding-which could be analysed in more detail in future research work-it is inevitable to have the impression that, for her, feminism appears as one of the chosen constituents of this narrativity of the self, as a mere "commercialised, branded form" (Seaton 159). ${ }^{21}$ This would constitute one example of Dara Persis Murray's assertion that in the utilitarian embracing of feminism for self-branding it is made evident how, in our neoliberal context, social issues are used as a means of generating sales (86).

From all these reflections, I conclude that Dunham gives the impression of having chosen hipsterism and feminism-both originally characterised by their subversive nature-as the core constituents of the self-identity not only of her fictional Girls characters-especially that of Hannah-but also of her own self. In this process of creation, authenticity is commodified, as it is a required component for the successful marketing of one's own brand. In the same way, when realism is surpassed in Girls, it shows the intention of gaining notoriety, which, even if considered proper of hipsterism and artists in general, also responds again to the commercial objectives of selling Dunham's brand and product. This attitude reminds us of the hipsters' morphism into rich industries that sell a mythical, neo-bohemian lifestyle that Elan describes.

\footnotetext{
20 The blurred distinction between Hannah and Dunham herself is also related to the typically neoliberal (auto)imposition of a self-branding based on authenticity-also a commercial appeal and tactic-, which is a very interesting subject to be analysed in the future.

21 Nash and Whelehan coincide with this interpretation when they refer to "Lena Dunham's outspoken brand of social-media friendly feminism" (1) and "her own brand of popular cultural feminism" (5).
} 
Consequently, we can conclude that Dunham fits in with Scott's consideration of hipsters as a subgroup within the petite bourgeoisie that "shifts from the world of consumption to the sphere of production" (62). Besides, following Genz's inferences, she can be said to correspond with the neoliberal self that Michel Foucault termed "homo oeconomicus," "a self-governing and autonomous entrepreneur who invests in their own human capital in order to realise their potential without the unnecessary intervention of an oppressive government" $(2017,19)$. But, as the latter warns, we have to be conscious of the distorted notion of freedom and individualisation that this practice conveys (Genz 2017, 19), because genuinely praiseworthy and communal goals-such as the original hipster rebelliousness against social impositions and those proper of feminism-are being used by producers in order to sell their selfbrands and their products merely in their own individual interests.

\section{WORKS CITED}

ALFREY, Lauren M. "The Search for Authenticity: How Hipsters Transformed from a Local Subculture to a Global Consumption Collective." Master's thesis, Georgetown University, Washington, 2010.

ARSEL, Zeynep, and Craig J. Thompson. "Demythologizing Consumption Practices: How Consumers Protect Their Field-Dependent Identity Investments from Devaluing Marketplace Myths." Journal of Consumer Research, vol. 37, no. 5, 2011, pp. 791-806, doi:10.1086/656389.

BANKS, Mark. The Politics of Cultural Work. Palgrave, 2007.

BAUMAN, Zygmunt. "Identity in the Globalising World." Social Anthropology, vol. 9, n.2, pp. 121-129.

BAUMGARDNER, Jennifer. "Williamsburg Year Zero." What Was the Hipster? A Sociological Investigation, edited by Mark Greif et al., $\mathrm{N}+1$ Foundation, 2010, pp. 92-96.

BELL, Katherine. "Obvie, We're the Ladies!" Postfeminism, Privilege, and HBO's Newest Girls." Feminist Media Studies, vol.13, n.2, 2013, pp. 363-366. 
BLACKMAN, Shane. "Subculture Theory: An Historical and Contemporary Assessment of the Concept for Understanding Deviance." Deviant Behavior, vol. 35, no. 6, 2014, pp. 496-512.

BOGOVIĆ, René. "Hipsters: Rebellion Commodified." Google Scholar. University of Toronto, pp. 1-19.

BOT, Sophy. The Hipster Effect; How the Rising Tide of Individuality is Changing Everything We Know about Life, Work and the Pursuit of Happiness, 2012.

BOURDIEU, Pierre. "The Forms of Capital." Handbook of Theory and Research for the Sociology of Education, John G. Richardson, editor. Greenwood, 1986, pp. 241-58.

BRAKE, Mike. The Sociology of Youth Culture and Youth Subcultures. Routledge, 1980.

BROYARD, Anatole. "A Portrait of the Hipster." Partisan Review, vol. 15, no. 6, 1948, pp. 721-27.

"Cab Calloway's A Hepster's Dictionary, a 1939 Glossary of the Lingo (the "Jive") of the Harlem Renaissance." Open Culture, January 19, 2015. Accessed 14 Oct. 2020.

CASINO, Katrina. "Why Lesbians Hang on to the Hipster." The Gay and Lesbian Review Worldwide, vol. 17, no. 5, 2010, pp. 25-27.

CLAYTON, Jace. "Vampires of Lima." What Was the Hipster? A Sociological Investigation, edited by Mark Greif et al., N+1 Foundation, 2010, pp. 24-30.

COWEN, Deborah. "Hipster Urbanism.” Relay, Sept./Oct., 2006, pp. 22-23. www.socialistproject.ca/relay/relay13_hipster.pdf. Accessed 14 Feb. 2021.

DANES, C. “The 2013 Time 100." Time. 18 Apr. 2013, time100.time.com/2013/04/18/time-100/slide/all/. Accessed 28 Jan. 2021.

DANES, Claire. "Lena Dunham." Interview. 1 Apr. 2012, www.interviewmagazine.com/film/lena-dunham-1. Accessed 28 Jan. 2021.

DUNHAM, Lena. Girls. HBO, 2012-2017. 
ELAN, Priya. "How Hipsters Took Over Television." The Guardian, 10 Sept. 2012, www.theguardian.com/tv-andradio/shortcuts/2012/sep/10/hipsters-make-perfect-sitcommaterial. Accessed 23 Jan. 2021.

ERIGHA, Maryann. "Working Girls? Millennials and Creative Careers." HBO's Girls: Questions of Gender, Politics, and Millennial Angst, edited by Betty Kaklamanidou and Margaret Tally, Cambridge Scholars Publishing, 2014, pp. 140-155.

FLORIDA, Richard. Cities and the Creative Class. Taylor \& Francis Group, 2004. ProQuest Ebook Central, ebookcentral.proquest.com/lib/bibliotecaumaebooks / detail.action?docID=237437.

GAY, Roxane. "Roxane Gay Talks to Lena Dunham about Her New Book, Feminism, and the Benefits of Being Criticized Online." Vulture, 2 Oct. 2014, www.vulture.com/2014/10/roxane-gay-interview-lenadunham-bad-feminist-not-that-kind-of-girl-books.html. Accessed 30 May 2021.

GENZ, Stéphanie. “I Have Work... I Am Busy... Trying to Become Who I Am’: Neoliberal Girls and Recessionary Postfeminism." Reading Lena Dunham's Girls. Feminism, Postfeminism, Authenticity and Gendered Performance in Contemporary Television, edited by Meredith Nash and Imelda Whelehan, Palgrave Macmillan, 2017, pp. 17-30.

GENZ, Stéphanie. "My Job Is Me: Postfeminist Celebrity Culture and the Gendering of Authenticity." Feminist Media Studies, vol.15, n.4, 2015, pp. 545-561.

GRANT, Ruby and Meredith Nash. "From Sex and the City to Girls: Paving the Way for 'Post? Feminism'." Reading Lena Dunham's Girls. Feminism, Postfeminism, Authenticity and Gendered Performance in Contemporary Television, edited by Meredith Nash and Imelda Whelehan, Palgrave Macmillan, 2017, pp. 61-74.

GREIF, Mark, et al. What Was the Hipster? A Sociological Investigation. N+1 Foundation, 2010.

HAMILTON, Nikita. "So They Say You Have a Race Problem? You're in Your Twenties, You Have Way More Problems Than That." HBO's Girls: Questions of Gender, Politics, and Millennial Angst, edited by Betty 
Kaklamanidou and Margaret Tally, Cambridge Scholars Publishing, 2014, pp. 43-58.

“HBO's Girls Looking for 'Hipster Types' of All Races for Second Season, Filming in Brooklyn." Huffington Post, 18 May 2012, www.huffpost.com/entry/hbos-girls-hipsters-diversity-greenpointbrooklyn-casting-call_n_1528179. Accessed 27 Dec. 2020.

HEBDIGE, Dick. Subculture: The Meaning of Style. Routledge, 1979.

HILL, Wes. "A Hipster History: Towards a Post-critical Aesthetic." Critical Studies in Fashion and Beauty, vol. 6, no. 1, 2015, pp. 45-60.

HOARE, Peter. "The 15 Hottest Hipster Actresses." Complex, 29 Oct. 2012, https://www.complex.com/pop-culture/2012/10/the-15-hottesthipster-actresses/. Accessed 27 Jan. 2021.

HUBER, Alison. "Mainstream as Metaphor: Imagining Dominant Culture." Redefining Mainstream Popular Music, edited by Sarah Baker, et al., Taylor \& Francis Group, 2013, pp. 3-13.

JACKSON, Greg. "Hipster Elegies," The Hedgehog Review Reader: Critical Reflections on Contemporary Culture, Summer, 2019, hedgehogreview.com/issues/reality-and-its-

alternatives/articles/hipster-elegies. Accessed 28 Jan. 2021.

JAMES, Kendra. "Dear Lena Dunham, I Exist." Medium, 26 Aug. 2016, medium.com/@KendraJames_/dear-lena-dunham-i-existdb4bf3cb7720. Accessed 23 Jan. 2021.

JENKS, Chris. Subculture: The Fragmentation of the Social. Sage Publications, 2005.

JOHNSON, Chloé H. "Dancing on My Own: Popular Music and Issues of Identity in Girls." HBO's Girls: Questions of Gender, Politics, and Millennial Angst, edited by Betty Kaklamanidou and Margaret Tally, Cambridge Scholars Publishing, 2014, pp.186-198.

KANAI, Akane. "On Not Taking the Self Seriously: Resilience, Relatability and Humour in Young Women's Tumblr Blogs." European Journal of Cultural Studies, vol. 22, n. 1, 2019, pp. 60-77.

KELLNER, Douglas. "Critical Perspectives on Television from the Frankfurt School to Postmodernism." A Companion to Television, edited by Janet Wasko, John Wiley \& Sons, Incorporated, 2005, pp. 29-47. 
KELSEY, Henke. "Postmodern Authenticity and the Hipster Identity." Forbes and Fifth, vol. 3, Spring, 2013, forbes5.pitt.edu/article/postmodernauthenticity-and-hipster-identity. Accessed 4 Feb. 2021.

KINZEY, Jake. The Sacred and the Profane; An Investigation of Hipsters. Zero, 2012.

KOZAK, Anna. "Hipsterception: A Critique of Popular Criticism of the Postmodern Hipster." March 2013, www.academia.edu/6226829/Hipsterception_A_Critique_of_Popular _Criticism_of_the_Postmodern_Hipster. Accessed 26 Apr. 2020.

LANHAM, Robert. The Hipster Handbook. Anchor Books, 2003.

LELAND, John. Hip: The History. Harper Perennial, 2005.

LEHMAN, Katherine J. “'All Adventurous Women Do": HBO's Girls and the 1960s-70s Single Woman." HBO's Girls: Questions of Gender, Politics, and Millennial Angst, edited by Betty Kaklamanidou and Margaret Tally, Cambridge Scholars Publishing, 2014, pp.10-28.

"Lena Dunham Cashes in on Hipster Culture." Glad2baWoman, 23 Oct. 2017, www.glad2bawoman.me/article/3116/category/achievers/lenadunham-cashes-hipster-culture. Accessed 27 Jan. 2021.

LIM, Thea. "A Historical Guide to Hipster Racism." Racialicious.com, May 2, 2012, www.racialicious.com/2012/05/02/a-historical-guide-tohipster-racism/ Accessed 26 Nov. 2020.

LORENTZEN, Christian. "Why the Hipster Must Die. A Modest Proposal to Save New York Cool." Time Out New York, 30 May 2007. Accessed 21 Jan. 2021.

MAHDAWI, Arwa. “Is Lena Dunham's 'Hipster Racism' Just Old-fashioned Prejudice?" The Guardian, 25 Nov. 2017, www.theguardian.com/world/2017/nov/25/hipster-racism-lenadunham-prejudice. Accessed 12 Feb. 2021.

MAILER, Norman. "The White Negro: Superficial Reflections on the Hipster." Dissent, Fall, 1979, pp. 276-93.

MAKARECHI, Kia. "Girls Reviews: New HBO Show and Lena Dunham Face Backlash on Racism and More." The Huffington Post, 16 Apr. 2012, 
www.huffpost.com/entry/girls-reviews-backlash-hboshow_n_1429328. Accessed 29 Oct. 2020.

MALLONEE, Laura. "Photos of Brooklyn before and after the Hipsters," Wired, 8 Sept. 2015, www.wired.com/2015/09/photos-brooklynhipsters/ Accessed 2 Febr. 2021.

MALONE, Noreen. "The Kids Are Actually Sort of Alright.” New York. 14 Oct. 2011, nymag.com/news/features/my-generation-2011-10/. Accessed 13 Jan. 2021.

MALY, Ico and Piia Varis. "The 21st-century Hipster: On Micro-populations in Times of Superdiversity." European Journal of Cultural Studies, vol. 19, no. 6, 2016, pp. 637-53.

MAU, Dhani. “'Girls' Costume Designer Talks Season 4 and Why Hannah's Clothes Fit So Badly." Fashionista, 8 Jan. 2015, fashionista.com/2015/01/girls-costumes-season-4. Accessed 5 Febr. 2021.

MCCANN, Hannah. "A Voice of a Generation': Girls and the Problem of Representation." Reading Lena Dunham's Girls. Feminism, Postfeminism, Authenticity and Gendered Performance in Contemporary Television, edited by Meredith Nash and Imelda Whelehan, Palgrave Macmillan, 2017, pp. 91-104.

MCROBBIE, Angela. Feminism and Youth Culture: From Jackie to Just Seventeen. Unwin Hyman, 1991.

---. British Fashion Design: Rag Trade or Image Industry? Taylor and Francis Group, 1998.

---. "Notes on the Perfect". Australian Feminist Studies, vol. 30, no. 83, 2015, pp. 3-20.

MENGER, Pierre-Michel. "Artistic Labor Markets and Careers." Annual Review of Sociology, vol. 25, 1999, pp. 541-74.

MILLER, Laura. "Girls Is Much More Than a Brooklyn Hipster Version of Sex and the City." Newstatesman, 6 Sept. 2012, www.newstatesman.com/culture/culture/2012/09/girls-muchmore-brooklyn-hipster-version-sex-and-city. Accessed 7 Feb. 2021. 
MICHAEL, Janna. "It Is Really Not Hip to Be a Hipster: Negotiating Trends and Authenticity in the Cultural Field." Journal of Consumer Culture, vol. 15, no. 2, 2015, pp. 163-82.

MULVEY, Laura. "Visual Pleasure and Narrative Cinema." Screen, vol. 16, no. 3, Autumn, 1975, pp. 6-18, https://doi.org/10.1093/screen/16.3.6, Accessed 7 Feb. 2021.

MURRAY, Dara Persis. "Branding 'Real' Social Change in Dove's Campaign for Real Beauty." Feminist Media Studies, vol.13, n- 1, 2013, pp. 83101.

MURRAY, Margaret Anne. "White, Male, and Bartending in Detroit: Masculinity Work in a Hipster Scene." Journal of Contemporary Ethnography, vol. 49, no. 4, 2020, pp. 456-480.

NASH, Meredith and Imelda Whelehan, editors. Reading Lena Dunham's Girls. Feminism, Postfeminism, Authenticity and Gendered Performance in Contemporary Television. Palgrave Macmillan, 2017.

NEWCOMB, Horace. "The Development of Television Studies." A Companion to Television, edited by Janet Wasko, John Wiley \& Sons, Incorporated, 2005, pp. 15-28.

NG., Eddy S. W., et al. "New Generation, Great Expectations: A Field Study of the Millennial Generation." Journal of Business and Psychology, vol. 25, no. 2, 2010, pp. 281-292. JSTOR, www.jstor.org/stable/40605786. Accessed 28 Oct. 2020, Accessed 7 Feb. 2021.

NORTON, Abra Deering. "HBO Girls: Hipsterism Gone Awry." SheKnows. 8 May 2012 , www.sheknows.com/entertainment/articles/959665/hbo-girlsepisode-recap-hannahs-diary/. Accessed 23 Jan. 2021.

PARK, Heejung, Jean M. Twenge, and Patricia M. Greenfield. "The Great Recession: Implications for Adolescent Values and Behavior." Social Psychological and Personality Science, vol. 5, no. 3, Apr. 2014, pp. 310-18. doi.org/10.1177/1948550613495419.

PEITZMAN, Louis. “It Costs a Lot of Money to Look This Cheap': Send in Your Most High-Priced 'Low-Class' Items." Gawker, 21 Apr. 2012, gawker.com/5903994/it-costs-a-lot-of-money-to-look-this-cheapsend-in-your-most-high-priced-low-class-items. Accessed 2 Febr. 2021. 
PLURALIST. "Lena Dunham Says Goodbye to Brooklyn Hipsters Who Judge Her 'Infertility and Loneliness'." 3 Dec. 2018, pluralist.com/lenadunham-says-goodbye-to-brooklyn-hipsters-who-judge-herinfertility-and-loneliness/. Accessed 4 Sept. 2020.

PONIEWOZIK, James. "Lena Dunham Interview, Part Two: The Personal Factor." Time. 13 Apr. 2012, entertainment.time.com/2012/04/13/lena-dunham-interview-parttwo-the-personal-factor/. Accessed 24 Nov. 2020.

QUENQUA, Douglass. "Seeing Narcissists Everywhere." The New York Times, $5 \quad$ Aug. 2013, https://www.nytimes.com/2013/08/06/science/seeing-narcissistseverywhere.html. Accessed 24 Nov. 2020.

RICHARDSON, John G., editor. Handbook of Theory and Research for the Sociology of Education. Greenwood, 1986.

ROSENBERG, Alyssa. "Girls: Inside the Eccentric Fashion of Lena Dunham's HBO Comedy." Daily Beast, 1 Oct. 2013, www.thedailybeast.com/girls-inside-the-eccentric-fashion-of-lenadunhams-hbo-comedy. Accessed 26 Oct. 2020.

RUÍZ, Nacho. "8 series para hipsters." El Mundo, 29 May 2017, www.elmundo.es/metropoli/cine/2017/05/24/5925b4ade2704e8b6 38b4654.html. Accessed 27 Jan. 2021.

SAISI, Boké. "Just White Girls?: Underrepresentation and Active Audiences in Girls." HBO's Girls: Questions of Gender, Politics, and Millennial Angst, edited by Betty Kaklamanidou and Margaret Tally, Cambridge Scholars Publishing, 2014, pp. 59-72.

SCHIERMER, Bjørn. "Late-modern Hipsters: New Tendencies in Popular Culture." Acta Sociologica, vol. 57, no. 2, 2014, pp. 167-81.

SCHWART, Karen. "The Clothes Make the 'Girls'." New York Times, 2 Jan. 2013, www.nytimes.com/2013/01/03/fashion/on-this-hit-showthe-clothes-make-the-girls.html. Accessed 25 Oct. 2020.

SCOTT, Michael. "'Hipster Capitalism' in the Age of Austerity? Polanyi Meets Bourdieu's New Petite Bourgeoisie." Cultural Sociology, vol. 11, no. I, 2017, pp. 60-76. 
SEATON, Wallis. “Doing Her Best With What She's Got': Authorship, Irony, and Mediating Feminist Identities in Lena Dunham's Girls." Reading Lena Dunham's Girls. Feminism, Postfeminism, Authenticity and Gendered Performance in Contemporary Television, edited by Meredith Nash and Imelda Whelehan, Palgrave Macmillan, 2017, pp. 149-162.

SEPINWALL, Alan. "Review: HBO's Girls Brilliantly Channels Lena Dunham's Comic Voice." Hitfix, 12 Apr. 2012, uproxx.com/sepinwall/reviewhbos-girls-brilliantly-channels-lena-dunhams-comic-voice/. Accessed 9 Apr. 2020.

SIMMEL, Georg. "Fashion.” International Quarterly, X, October, 1904, pp.: 130-155, Rpt. in The American Journal of Sociology, vol.62, no.6, May 1957, pp. 541-558.

SPIEGEL, Alison. "The 22 Most Hipster Foods on The Planet." Huffpost, 17 Apr. 201, https://www.huffpost.com/entry/hipsterfood_n_5146632. Accessed 9 Oct. 2021.

STEIN, Joel. "Millennials: The Me Me Me Generation." Time. 20 May 2013, time.com/247/millennials-the-me-me-me-generation/. Accessed 23 Jan. 2020.

STEWART, Dodai. "Why We Need to Keep Talking About the White Girls on Girls." Jezebel, 19 Apr. 2012, jezebel.com/why-we-need-to-keeptalking-about-the-white-girls-on-gi-5903382. Accessed 23 Jan. 2020.

STUEVER, Hank. "HBO's 'Girls' Goes Out as the One Thing It Always Wanted to Be: A Good TV Show." Washington Post, 14 Apr. 2017, www.washingtonpost.com/entertainment/tv/hbos-girls-goes-out-asthe-one-thing-it-always-wanted-to-be-a-good-tvshow/2017/04/13/bf1bda9a-1fc0-11e7-a0a78b2a45e3dc84_story.html. Accessed 23 Oct. 2020.

SUEBSAENG, Asawin. Girls: "What the Hell Was HBO Thinking?" Mother Jones. 11 Apr. 2012, www.motherjones.com/politics/2012/04/tvreview-girls-hbo-lena-dunham/. Accessed 27 Oct. 2020.

THORNTON, Sarah. Club Cultures: Music, Media and Subcultural Capital. Blackwell Publishers, 2001. 
TORTORICI, Dayna. "You Know It When You See It". What Was the Hipster? A Sociological Investigation, edited by Mark Greif et al., $\mathrm{N}+1$ Foundation, 2010, pp. 122-35.

TOUS-ROVIROSA, Anna, Koldo Meso Ayerdi, and Nuria Simelio, "The Representation of Women's Roles in Television Series in Spain. Analysis of the Basque and Catalan Cases." Communication \& Society/Comunicación y Sociedad, vol. 26, no. 3, 2013, pp. 67-97.

VANARENDONK, Kathryn. "Hannah on Girls Could Not Have Gotten That Job." Vulture. April 11, 2017.

WAMPOLE, Christy. "How to Live Without Irony." The New York Times. 17 Nov. 2012, opinionator.blogs.nytimes.com/2012/11/17/how-to-livewithout-irony/. Accessed 4 Febr. 2021.

WASKO, Janet, editor. A Companion to Television. John Wiley \& Sons, 2005.

WEESE, Matt. "Why Hipsters Love to Hate Girls." HBO Watch, 19 Sept. 2013, hbowatch.com/why-hipsters-love-to-hate-girls/ Accessed 27 Oct. 2020.

WELLER, Wivian. "The Feminine Presence in Youth Subcultures: The Art of Becoming Visible." Estudos. Feministas, vol.1. 2006.

http://socialsciences.scielo.org/scielo.php?script=sci_arttext\&pid=S 0104-026X2006000100003\&lng=en\&nrm=iso.

Accessed 12 Oct. 2021.

WEISSMAN, Jerry. “Lena Dunham's Secret to Success.” Forbes, 8 Oct. 2014. Accessed 27 Oct. 2019.

WEST, Lindy. "A Complete Guide to 'Hipster Racism'.” Jezebel.com, 26 Apr. 2012, jezebel.com/5905291/a-complete-guide-to-hipster-racism. Accessed 27 Oct. 2020.

WINCHELL, Casey. "HBO's Girls: The Hipster-fied Sex and the City." Minx Society, March, 2012. Accessed 27 Jan. 2020.

WOLFGANG, Marvin and Franco Ferracuti. The Subculture of Violence: Towards an Integrated Theory in Criminology. Tavistock, 1967.

WORTHAN, Jenna et al. "Voice, Vice, Veracity." The New York Times, vol. 5, February 2017, p. 1. 
The Hipster Subculture and its Representation

in Lena Dunham's TV series Girls

---. "Where (My) Girls At?” The Hairpin, thehairpin.com/2012/04/where-mygirls-at/. 16 Apr. 2012. Accessed 23 Jan. 2020. 